\title{
Biologinių preparatų ir bioorganinių trąšų naudojimas cukrinių runkelių pasèliuose
}

Elena Jakienè,

\author{
Vidmantas Spruogis \\ Aleksandro Stulginskio universitetas, \\ Studentu g. 11, \\ LT-53361 Akademija, Kauno r. \\ El.paštaselena.jakiene@asu.lt
}

Sparčiai vystantis žemès ūkiui, taikant intensyvias lauko augalų auginimo technologijas, gausiai tręšiant ir naudojant daug augalų apsaugos priemonių, neišvengiamai blogèja dirvožemio būklè. Tai tampa ribojančiu veiksniu potencialiam augalu derlingumui gauti. Vienas iš būdų dirvožemio aktyvumui ir augalų produktyvumui didinti - biologinių preparatų bei bioorganinių trąšų naudojimas.

Tyrimų tikslas - nustatyti tirtujų biologinių preparatų ir bioorganinių trąšų įtaką cukrinių runkelių produktyvumo pokyčiams augalus apipurškiant skirtingais jų augimo ir vystymosi tarpsniais.

Lauko bandymai atlikti Aleksandro Stulginskio universiteto Bandymų stotyje 2011-2013 metais. Tirta papildomo tręšimo per lapus biologinių preparatų Azofit $11 \mathrm{ha}^{-1}$, Nagro $11 \mathrm{ha}^{-1}$, Bioplant Flora $11 \mathrm{ha}^{-1}$ ir Raskila $21 \mathrm{ha}^{-1}$ tirpalais ittaka 'Ernestina' veislès cukrinių runkelių (Beta vulgaris L., var. saccharifera) produktyvumui. Prieš sèją bandymų laukas patręštas NPK 5:15:30 $400 \mathrm{~kg} \mathrm{ha}^{-1}$ ir papildomai amonio salietra $\left(\mathrm{N}_{34}\right) 180 \mathrm{~kg} \mathrm{ha}^{-1}$ (foninis viso bandymo tręšimas - kontrolè). Cukriniai runkeliai biologinių preparatų tirpalais apipurkšti $16 \mathrm{BBCH}, 21 \mathrm{BBCH}$ ir $33 \mathrm{BBCH}$ vieną kartą, du kartus $16+21 \mathrm{BBCH}$ ir tris kartus $16+21+33 \mathrm{BBCH}$ augimo tarpsniais. Kitos agrotechninès priemonės buvo atliktos pagal Bandymų stotyje taikomą cukrinių runkelių auginimo technologiją. Cukrinių runkelių derlius nuimtas spalio 10 dieną. Šakniavaisių cukringumas nustatytas UAB „Arvi cukrus“ Marijampolès cukraus fabriko laboratorijoje šaltosios digestijos metodu.

Gauti bandymo rezultatai parodè, kad cukrinius runkelius tirtaisiais biologiniais preparatais apipurškus vieną kartą didžiausias šakniavaisių derlius ir geriausia kokybė gauti panaudojus Azofit 1 arba Nagro $11 \mathrm{ha}^{-1}$ tirpalus $21 \mathrm{BBCH}$ augimo tarpsniu. Taip apipurškus cukrinių runkelių derlingumas patikimai padidejo atitinkamai 8,50 ir 9,19 $\mathrm{t} \mathrm{ha}^{-1}$, šakniavaisių cukringumas $-0,81$ ir 1,03 proc. vnt., baltojo cukraus kiekis gautas 1,52 ir $1,90 \mathrm{t} \mathrm{ha}^{-1}$ patikimai didesnis, palyginti su kontroliniuose laukeliuose augusiais cukriniais runkeliais.

Cukrinius runkelius biologinių preparatų ir bioorganinių trąšų Azofit arba Nagro tirpalais apipurškus du kartus $(16+21 \mathrm{BBCH})$, šakniavaisių derlingumas patikimai padidèjo 9,29 ir 9,56 $\mathrm{t} \mathrm{ha}^{-1}$, cukringumas $-0,99$ ir 1,14 proc. vnt., baltojo cukraus gauta 1,88 ir 2,03 $\mathrm{t} \mathrm{ha}^{-1}$ patikimai daugiau, palyginti su kontrole. Du kartus augalus apipurškus biologinių preparatų Bioplant Flora 1 arba Raslila $21 \mathrm{ha}^{-1}$ tirpalais, šakniavaisių derlingumas patikimai padidëjo 7,34 ir 6,42 $\mathrm{tha}^{-1}$, cukringumas $-0,83$ ir 0,62 proc. vnt., baltojo cukraus gauta 1,51 ir $1,24 \mathrm{t} \mathrm{ha}^{-1}$ patikimai daugiau, palyginti su kontrole, kur biologiniai preparatai nebuvo naudoti.

Cukrinius runkelius tirtųjų biologinių preparatų tirpalais apipurškus tris kartus $(16+21+33 \mathrm{BBCH})$, produktyvumo pokyčiai nebuvo esminiai didesni, palyginti su gautais rezultatais, augalus biologinių preparatų tirpalais apipurškus du kartus.

Raktažodžiai: cukriniai runkeliai, biologiniai preparatai, bioorganinès trąšos, derlingumas, šakniavaisių cukringumas 


\section{IVADAS}

Šiuolaikinès augalininkystės uždavinys - užauginti ekologiškai nepavojingą, aukštos kokybès derliu su optimaliomis išlaidomis. Formuojant produktyvų cukrinių runkelių pasèlį vienas svarbiausių agrotechnikos elementų yra tręšimo produktų tobulinimas. Kuriamos naujos kartos trąšos aktyvuoja augalų fiziologinius procesus ir leidžia augalams realizuoti užkoduotas genetines galimybes (Deveikyte, 2009; Mickevičius ir kt., 2013).

Intensyvus trąšu ir pesticidų naudojimas augalininkystėje mažina dirvos biologinị aktyvumą, nes tai, kas naikina kenkejjus, ligų sukèlejus, naikina ir gerąsias bakterijas, kurios padeda išlaikyti dirvožemi produktyvų. To pasekmé - augančios išlaidos siekiamam derliui gauti. Esant nepakankamam dirvos biologiniam aktyvumui augalinès liekanos užteršia dirvą patogenais, susidaro nepalankios sąlygos mikrobiologiniams procesams, dirva kietejja, nekvèpuoja, susilaiko drègmé, augalų šaknys atsiduria nepalankiose sąlygose ir pradeda pūti (Suojala, 2000; Šiuliauskas ir kt., 2012).

Dirvožemyje randama iki 3000 skirtingų mikroorganizmų rūšių, kurių viena iš pagrindinių funkcijų yra užtikrinti natūralų dirvožemio derlingumą. Ivairios bakterijos, grybai, kiti dirvožemio mikroorganizmai aprūpina augalus maisto medžiagomis ir fermentais, kurie užtikrina tolygų lauko augalų vystymąsi. Pūdydamos ir skaidydamos daugybę tonų i̇vairiausių nuokritų, įvairių organinių atliekų, jos dirvožemyje pagausina humuso, kuris itin svarbus dirvožemio derlumui (Darginavičienè ir kt., 2002; Dewar et al., 2006).

Viena iš svarbiausių bakterijų funkcijų - dalyvauti azoto junginių apytakos cikle ir fiksuoti azotą. Daugiausia azoto sukaupiantis ir atspariausias neigiamiems aplinkos veiksniams azotą fiksuojančiu bakterijų porūšis yra Azotobacter vinelandii. Šios bakterijos veikia paviršiniame dirvožemio sluoksnyje, kuriame laisvai cirkuliuoja deguonis. Fiksuodamos atmosferos azotą $\mathrm{N}_{2}$ ir skaidydamos organines medžiagas Azotobacter vinelandii, priklausomai nuo dirvožemio ir klimato sąlygų, per vegetacijos periodą 1 ha dirvožemio gali sukaupti nuo 24 iki $80 \mathrm{~kg}$ azoto veikliosios medžiagos. Bakterijų sukauptas azotas yra laisvai prieinamas augalams, atstato dirvožemio biologini aktyvumą, kadangi sukauptą azotą naudoja ir kitos naudingosios dirvožemio bakterijos (Pidgeon et al., 2006; Drulis, 2014).
Fosforas - vienas sunkiausiai augalams prieinamu mitybos elementų. Ariamojo dirvos sluoksnio 1 ha yra nuo 1 iki $10 \mathrm{t}$ augalams neprieinamo fosforo. Augalai fosfora pasisavina esant neutraliam dirvos pH. Rūgščiose ar karbonatingose dirvose fosforą absorbuoja geležies, mangano, magnio jonai ir sudaro augalams neprieinamus junginius. Kad bent dalis fosforo taptų augalams prieinama, $\dot{x}$ pagalbą pasitelkiamos fosforą atpalaiduojančios $\mathrm{Ba}$ cillus megaterium var. Phosphaticum bakterijos. Per mènesi po purškimo šios bakterijos dirvožemyje esančio augalams prieinamo fosforo kieki padidina iki $21 \%$, o po dviejų mènesių - net iki $32 \%$ (Mickevičius ir kt., 2013; Drulis, 2014).

Šiandienos sąlygomis padidinti lauko augalų derlingumą galima diegiant moksliniais tyrimais pagrịstas naujas technologijas. Tai reiškia, kad naudojamos mineralinès trąšos, kurių sudètyje yra fitohormonų, laisvųjų aminorūgščių, huminių rūgščių, bakterijų, padedančios maksimaliai išnaudoti biologini augalų derlingumo potencialą. Naudojant tokias trąšas sustiprinamas mitybos elementu pasisavinimas, nealinama dirva bei optimizuojamas būsimo derliaus produktyvumas (Narkevičius ir kt., 2004; Lawlor, 2005; Jakienè ir kt., 2008; Šlapakauskas ir kt., 2008).

Aleksandro Stulginskio universiteto Bandymų stotyje atliktais tyrimais nustatyta, kad tręšiant bakteriniais preparatais apdorotomis trąšomis gaunamas iki $700 \mathrm{~kg} \mathrm{ha}^{-1}$ didesnis žieminių kviečių ir iki $11 \mathrm{t} \mathrm{ha}^{-1}$ didesnis cukrinių runkelių derlius. Padidèjęs dirvos biologinis aktyvumas teigiamai veikia ir cukrinių medžiagų kaupimąsi augaluose. Cukrinių runkelių šakniavaisių cukringumas padidejja apie 0,8-1,0 proc. vnt. (Šiuliauskas ir kt., 2008; Romaneckas ir kt., 2009).

Mokslininkams pavyko sukurti štamus ir ju dauginimo technologiją, leidžiančią biologinius preparatus derinti su cheminiais preparatais. Toks suderinamumas sumažina kultūrinių augalų stresus dèl cheminių medžiagų ir pagerina bendrą dirvožemio ir augalų būklę. Apdorojus augalu sèklas Azofitu arba preparatą išpurškus su herbicidais, fungicidais, augalai daug geriau pasisavina mineralines medžiagas, todèl galima mažiau tręšti mineralinėmis trąšomis, padidejja mineralinių trąšu efektyvumas ir augalu produktyvumas. Derinant su tinkama agrotechnika gaunamas iki $15 \%$ didesnis derlius. Pavyzdžiui, naudojant biologini preparatą Azofit su herbicidais kultūriniai augalai 
praktiškai nepatiria streso (Deveikytè, 2000; Shpaar, 2006).

Dauguma biologinių preparatų pasižymi specifiniu, jiems būdingu veikimu. Preparatas Azofit pagerina mikroorganizmų ir gerųų grybų aktyvumą augalų šaknų rizosferoje, o panaudojus Fosfix, augalai geriau išnaudoja dirvoje esantị ir augalams sunkiai prieinamą fosforą. Sèklų apvèlimas šiuo preparatu padidina fosforo pasisavinimą vidutiniškai 6-10 \% (Drulis, 2014). Penergetikų grupès preparatai leidžiami naudoti ir ekologiniuose ūkiuose. Prieš seją sẻklas apdorojus biologiniu preparatu Penergetik šaknims, augalai geriau šaknijasi, išsivysto stipri šaknų sistema, padedanti augalui geriau pasisavinti maisto medžiagas iš dirvožemio. Chemizuotuose ūkiuose šis preparatas maišomas su beicais (Novickienè 1994; Jakienè ir kt., 2009).

Reikia vertinti ne tik biologinių preparatų ittaką derlingumui, bet ir tai, kad pagerèja dirvožemio savybès. Mokslininkų nustatyta, kad naudojant biologinius preparatus 2-3 metus išlaidos kurui sumažèja 30-40\%. Taip pat tikimasi, kad bus galima sumažinti išlaidas trąšoms, nes biologiškai aktyviame dirvožemyje augalai geriau pasisavina fosforą. Sveikame dirvožemyje rečiau plinta ligos, todèl reikès nedidelio kiekio fungicidų, mažiau bus teršiama aplinka (Romaneckas ir kt., 2001; Staugaitis ir kt., 2008).

Tyrimų tikslas - nustatyti tirtųjų biologinių preparatų ittaką cukrinių runkelių produktyvumo pokyčiams biologiniais preparatais cukrinius runkelius apipurškiant skirtingais jų augimo ir vystymosi tarpsniais.

\section{TYRIMŲ METODAI IR SĄLYGOS}

Tikslieji lauko bandymai atlikti 2011-2013 m. Aleksandro Stulginskio universiteto Bandymų stotyje, karbonatingame sekliai glejiškame išplautžemyje (Calc(ar)i-Epihypogleyic Luvisols), IDg8-k (LVg-p-w-cc). Dirvožemis neutralios arba silpnai šarminès reakcijos - $\mathrm{pH} 7,2$, hidrolizinis rūgštumas $-1,80$ mekv. $100 \mathrm{~g}^{-1}$, sorbuotu bazių suma $-19,0$ mekv. $100 \mathrm{~g}^{-1}$, bendrojo azoto 0,155 \%, judriojo fosforo $\left(\mathrm{P}_{2} \mathrm{O}_{5}\right)-238-250 \mathrm{mg} \mathrm{kg}^{-1}$, judriojo kalio $\left(\mathrm{K}_{2} \mathrm{O}\right)$ - 154-172 $\mathrm{mg} \mathrm{kg}^{-1}$, humuso - 1,70$2,45 \%$. Dirvožemio analizès atliktos šiais metodais (naudojantis norminiais aktais): dirvožemio $\mathrm{pH} 1 \mathrm{~N} \mathrm{KCl}$ ištraukoje - potenciometriniu (ISO 10390: 2005), judrieji fosforas ir kalis (A-L)
Egnerio-Rimo-Domingo (GOST 26208-84), humuso kiekis - Tiurino (ISO 10694: 1995).

Cukraus išeiga apskaičiuota pagal formulę:

$\mathrm{A}=\mathrm{B}-0,9-\mathrm{C}$;

A - cukraus išeiga \%,

B - šakniavaisių cukringumas \%,

0,9 - cukraus nuostolių iki melasos koeficien-

tas,

C - cukraus nuostoliai melasoje (koef. 3,38).

Baltojo (kristalinio) cukraus kiekis (Ck) apskaičiuotas pagal formulę:

$\mathrm{Ck}=\mathrm{D} \cdot \mathrm{A} / \mathrm{100}$

$\mathrm{Ck}$ - baltojo cukraus kiekis $\mathrm{t} \mathrm{ha} \mathrm{a}^{-1}$,

$\mathrm{D}$ - šakniavaisių derlingumas $\mathrm{t} \mathrm{ha}^{-1}$.

Cukrinių runkelių šakniavaisių cukringumo analizès atliktos UAB „Arvi cukrus“ Marijampoles fabriko laboratorijoje. Eksperimento duomenys statistiškai apdoroti ịvertinant mažiausio esminio skirtumo ribą $\left(\mathrm{R}_{05}\right)$ kompiuterine programa ANOVA (Tarakanovas, Raudonius, 2003). Skaičiavimai atlikti Aleksandro Stulginskio universitete, Žemès ūkio ir maisto mokslų institute.

Tikslieji lauko bandymai vykdyti pagal schemą:

1. Kontrole ( $\mathrm{F}$ - foninis viso bandymo tręšimas NPK; biologiniai preparatai nenaudoti)

2. F + Azofit 11 ha $^{-1}$

3. $\mathrm{F}+$ Bioplant Flora 11 ha $^{-1}$

4. F + Nagro 11 ha $^{-1}$

5. F + Raskila 21 ha $^{-1}$; purkšta 1 kartą $16 \mathrm{BBCH}$

6. F + Azofit 11 ha $^{-1}$

7. $\mathrm{F}+$ Bioplant Flora $11 \mathrm{ha}^{-1}$

8. F + Nagro 11 ha $^{-1}$

9. F + Raskila 21 ha $^{-1}$; purkšta 1 kartą $21 \mathrm{BBCH}$

10. $\mathrm{F}+$ Azofit 11 ha $^{-1}$

11. F + Bioplant Flora 11 ha $^{-1}$

12. F + Nagro 11 ha $^{-1}$

13. F + Raskila 21 ha $^{-1}$; purkšta 1 kartą 33 $\mathrm{BBCH}$

14. $\mathrm{F}+$ Azofit 11 ha $^{-1}$

15. $\mathrm{F}+$ Bioplant Flora $11 \mathrm{ha}^{-1}$

16. $\mathrm{F}+$ Nagro $11 \mathrm{ha}^{-1}$

17. F + Raskila 21 ha $^{-1}$; purkšta 2 kartus $16+21$

$\mathrm{BBCH}$

18. $\mathrm{F}+$ Azofit 11 ha $^{-1}$

19. F + Bioplant Flora 11 ha $^{-1}$

20. F + Nagro 11 ha $^{-1}$

21. F + Raskila 21 ha $^{-1}$; purkšta 3 kartus $16+21+33 \mathrm{BBCH}$

Cukriniai runkeliai biologiniu preparatų tirpalais apipurkšti augimo tarpsniais: $16 \mathrm{BBCH}-4$ 
poros tikrųjų lapų; $21 \mathrm{BBCH}-6$ poros tikrųjų lapų; $33 \mathrm{BBCH}$ - lapai dengia $30 \%$ dirvos (Meier, 2001).

Lauko bandymas vykdytas 4 pakartojimais. Pradinis bandymų laukelių plotas $12,6 \mathrm{~m}^{2}$, apskaitomojo laukelio plotas - 9,0 $\mathrm{m}^{2}$. Laukelių išdėstymas - sisteminis. Cukrinių runkelių tarpueilio plotis $-45 \mathrm{~cm}$, atstumas tarp sèklų sèjos metu - $16 \mathrm{~cm}$ (apie 134 tūkst. augalų hektare). Auginta cukrinių runkelių veislè 'Ernestina'. Tai diploidinè, derlinga, vidutinio cukringumo, pasižyminti gera baltojo cukraus išeiga. Vienadaigių cukrinių runkelių hibridinė veislè sukurta Vokietijoje, KWS SAAT AG selekcijos - sèklininkystès firmoje, veislè tolerantiška rizomanijai. Cukrinių runkelių priešsèlis - žieminiai kviečiai.

Lauko bandymuose naudoti biologiniai preparatai: Azofit - tai mikrobiologinès trąšos, kurios gerina dirvos struktūrą, todèl augalai geriau pasisavina mineralinius ir organinius mitybos elementus, esančius dirvoje, aktyvuoja atmosferoje esančio azoto pasavinimą, mobilizuoja sunkiai augalams prieinamus mitybos elementus, ypač fosforą ir kai kuriuos mikroelementus, aktyvuoja naudingąsias dirvos bakterijas, užtikrinančias lauko augalų produktyvumo didejimą ir produkcijos kokybès gerejjimą, veikia kaip augimo stimuliatorius, gerina sẻklų lauko daigumą, stimuliuoja šaknų augimą, skatina šiaudų mineralizaciją.

Preparato sudètis: azotą fiksuojančių bakterijų Azotobacter vinelandii $1 \times 10^{9} \mathrm{ml} / 5 \%$ kietujuc medžiagų, 4,5\% huminių rūgščių, $0,5 \%$ giberelino rūgšties, $0,01 \%$ vario $(\mathrm{Cu}), 0,01 \%$ cinko $(\mathrm{Zn})$, $0,01 \%$ mangano $(\mathrm{Mn}), 0,01 \%$ geležies $(\mathrm{Fe}), 0,01 \%$ kalcio $(\mathrm{Ca}), 0,005 \%$ natrio molibdato $\left(\mathrm{Na}_{2} \mathrm{Mo}_{04}\right)$ (kustodija.lt/azofit).

Bioplant Flora - skystos organinès trąšos, susidedančios iš lengvai pasisavinamų medžiagų, mikroelementų chalatine forma ir naudingos dirvožemio mikrofloros. Jų sudètyje yra humatų, fulvo ir aminorūgščių, vitaminų, gamtinių fitohormonų, augimą skatinančių medžiagų, makro- ir mikroelementų. Bioplant Floros gamyboje taikomos maitinamųjų ir biologiškai aktyvių medžiagų stambių molekulinių darinių smulkinimo nanotechnologijos. Dèl lengvai prieinamų huminių junginių formų yra skatinamas augalų augimas, stiprejja jų imuninè sistema, gerejja maitinamųju elementų pasisavinimas iš dirvos ir augale. Trąšų sudètyje esančių mikroelementų kompleksas skatina oksidacinị aktyvumą (deguonies apytaką) ir tokiu būdu stimuliuoja kvèpavimo ir fotosintezès procesus.

Skystos organinès trąšos Bioplant Flora sudètis (Rusijoje akredituotos laboratorijos ANO „NIES“ duomenys): $\mathrm{pH}$ koncentratas - 9,12; sausosios medžiagos - 27,09 $\mathrm{g} \mathrm{l}^{-1}$; azotas $(\mathrm{N})-1,12 \mathrm{~g} \mathrm{l}^{-1}$; fosforas $(\mathrm{P})-0,08 \mathrm{~g} \mathrm{l}^{-1}$; kalis $(\mathrm{K})-0,54 \mathrm{~g} \mathrm{l}^{-1}$; organinès medžiagos - $9,96 \mathrm{~g} \mathrm{l}^{-1}$; suminè anglis (C) $-4,98 \mathrm{~g} \mathrm{l}^{-1}$; huminès rūgšties anglis $-3,54 \mathrm{~g} \mathrm{l}^{-1}$; fulvo rūgšties anglis - 1,44 $\mathrm{g} \mathrm{l}^{-1}$; huminių ir fulvo rūgščių suma - 9,90 $\mathrm{g}^{-1}$; huminių rūgščių ne mažiau - 6,66 $\mathrm{g} \mathrm{l}^{-1}$; fulvo rūgščių ne mažiau $-3,24 \mathrm{~g} \mathrm{l}^{-1}$; mikroelementai: $\mathrm{Fe}, \mathrm{Zn}, \mathrm{Mg}, \mathrm{Mn}, \mathrm{Mo}, \mathrm{B}, \mathrm{Ca}, \mathrm{Cu}$, $\mathrm{Co}$, Se ir kitos biologiškai aktyvios medžiagos (bioenergy.LT/Bioplant flora).

Bioorganinès kompleksinès trąšos NAGRO universal - idealiai subalansuota mikroelementai, makroelementai ir kitos biologiškai aktyvios medžiagos. Labai gerai tinka tręšti per lapus tiek rudeni žieminius javus ir žieminius rapsus, tiek pavasarị dar ir vasarinius javus, rapsus, runkelius, kukurūzus, žalienas. Labai padidina augalų derlių ir pagerina produkcijos kokybės rodiklius. Paankstina augalų augimą ir vystymąsi. Trąšu sudètyje yra itin aktyvios pieno rūgšties, azotą fiksuojančių, fosfatus sutelkiančių, fotosintezès ir celiuliolitiniu bei lignolitinių mikrobų biologinių formų. Pseudomonas aureofaciens bakterijos - gyvybinès veiklos procese gamina visą kompleksą antibiotinių medžiagų, kurios slopina patogeninių grybelių ir bakterijų vystymąsi iki jų sunaikinimo: makroelementai ir mikroelementai, aminorūgštys, mikrohumatai, silicio junginiai.

Bioorganinių trąšų NAGRO universal sudètis: fulvo ir huminès rūgštys $6,21 \mathrm{~g} \mathrm{l}^{-1}$; azotas (N) 0,42 $\mathrm{g} \mathrm{l}^{-1}$; fosforas (P) 0,392 $\mathrm{g} \mathrm{l}^{-1}$; kalis (K) 2,568 $\mathrm{g} \mathrm{l}^{-1}$; Mg 260,2 $\mathrm{mg} \mathrm{l}^{-1}$; B 3,52 $\mathrm{mg} \mathrm{l}^{-1}$; Cu $0,78 \mathrm{mg} \mathrm{l}^{-1}$; Fe 86,41 $\mathrm{mg} \mathrm{l}^{-1}$; Mn 376,3 $\mathrm{mg} \mathrm{l}^{-1}$; Mo 686,9 $\mathrm{mg} \mathrm{l}^{-1}$; Zn 259,5 $\mathrm{mg} \mathrm{l}^{-1}$; Co 46,62 $\mathrm{mg} \mathrm{l}^{-1}$; Se $0,153 \mathrm{mg} \mathrm{l}^{-1}$; Cd 0,177 $\mathrm{mg} \mathrm{l}^{-1}$; Cr 0,08 $\mathrm{mg} \mathrm{l}^{-1}$; Ni $1,05 \mathrm{mg} \mathrm{l}^{-1}$; org. medžiagos $6,12 \mathrm{~g} \mathrm{l}^{-1}$; org. anglis $3,13 \mathrm{~g} \mathrm{l}^{-1}$ (nanonagro.lt/nagro-universalios-trasos).

Skystos organinès trąšos Raskila - tai koncentruotas produktas, pagamintas iš natūralaus, ekologiškai švaraus vermihumuso naudojant ypatingą gamybos technologiją. Skystoje organinèje trąšoje išsaugoti visi ekologiško vermihumuso komponentai. Produkto sudètyje yra visas kompleksas makro- ir mikroelementų, huminių medžiagų, augimo ir vystymosi hormonų, fulvo ir aminorūgščių, 
fitovitaminų. Moksliniais tyrimais patvirtinta, kad naudojant ši produktą augalai pasisavina daugiau maistinių medžiagų, sumažejja nitratų ir sunkiųjų metalų. Produktas naudojamas kaip dygimo ir augimo stimuliatorius, skatina geresnị šaknų ir antžeminès dalies vystymąsi.

Trą̌sos sudètis: sausoje medžiagoje - organinès medžiagos 33,33\%, NPK ne mažiau $4 \mathrm{~g} \mathrm{l}^{-1}$, huminių rūgščių ne mažiau $3 \mathrm{~g} \mathrm{l}^{-1}$, fulvo rūgščių ne mažiau $3 \mathrm{~g} \mathrm{l}^{-1}$, organinès anglies 0,34 \%, mikroelementų: $\mathrm{Fe}, \mathrm{Zn}, \mathrm{Mg}, \mathrm{Mn}, \mathrm{Mo}, \mathrm{B}, \mathrm{Ca}, \mathrm{Cu}$, koncentrato $\mathrm{pH}$ ne mažiau 7,5 (raskila.lt).

\section{Cukrinių runkelių auginimo agrotechnika ASU Bandymų stotyje}

Pavasarị, pradejjus įdirbti pradžiūvusią dirvą, atliktas foninis bandymo tręšimas - išbertos kompleksinès NPK trąšos santykiu 5:15:30 $400 \mathrm{~kg} \mathrm{ha}^{-1}$ (1 lentelè). Dirva sejjos dieną įdirbta ir pasèti 'Ernestina' veislès cukriniai runkeliai. Tuoj po sejos išpurkštas dirvinis herbicidas Fiesta (v. m. kvinmerakas $60 \mathrm{~g} \mathrm{l}^{-1}$ ir chloridazonas $\left.360 \mathrm{~g}^{-1}\right) 5,0 \mathrm{l} \mathrm{ha}^{-1}$.

Atsinaujinus piktžolių dygimui, laukas nupurkštas herbicidu Betanal maxxPro (v. m. desmedifamas $47 \mathrm{~g} \mathrm{l}^{-1}$, etofumezanas $75 \mathrm{~g} \mathrm{l}^{-1}$, lenacilas $27 \mathrm{~g} \mathrm{l}^{-1}$, fenmedifamas $60 \mathrm{~g} \mathrm{l}^{-1}$ ) $1,33 \mathrm{l} \mathrm{ha}^{-1}$. Gegužès mèn. antrą dekadą laukas papildomai patręštas amonio salietra $\left(\mathrm{N}_{34}\right)$, išberta $180 \mathrm{~kg} \mathrm{ha}^{-1}$. Cukriniams runkeliams užauginus 4 poras tikrųju lapų (16 BBCH), bandymo laukeliai pagal schemą apipurkšti biologinių preparatų tirpalais. Dar kartą piktžolès naikintos gegužès mèn. trečią dekadą - laukas nupurkštas herbicidu Betanal maxxPro $1,33 \mathrm{l} \mathrm{ha}^{-1}$. Insekticidas Proteus (v. m. tiaklopridas $100 \mathrm{~g} \mathrm{l}^{-1}$ ir deltametrinas $10 \mathrm{~g} \mathrm{l}^{-1}$ ) panaudotas birželio pradžioje, išpurkšta $0,75 \mathrm{l} \mathrm{ha}^{-1}$ tirpalo. Po dešimties dienų cukriniai runkeliai papildomai patręšti amonio salietra $\left(\mathrm{N}_{34}\right) 200 \mathrm{~kg} \mathrm{ha}^{-1}$.

Cukriniams runkeliams užauginus šešias poras tikrųjų lapų (21 augimo tarpsnis pagal BBCH skalę), augalai pagal bandymo schemą antrą kartą apipurkšti biologinių preparatų tirpalais. Liepos mèn. viduryje bandymų laukas nupurkštas fungicido Maredo (v. m. epoksikonazolas $125 \mathrm{~g} \mathrm{l}^{-1}$ ) 0,8 $\mathrm{l} \mathrm{ha}^{-1}$ tirpalu. Cukrinių runkelių lapams uždengus apie $30 \%$ dirvos (33 $\mathrm{BBCH})$, bandymo laukeliai pagal schemą trečią kartą apipurkšti tirtujų biologinių preparatų tirpalais. Cukrinių runkelių derlius nuimtas spalio mèn. pirmą dekadą rankiniu būdu panaudojant traktorinị šakniavaisių keltuvą.

\section{Meteorologinès sąlygos}

$2011 \mathrm{~m}$. cukrinių runkelių sèjai ir sèkloms dygti nebuvo palankūs. Sejos metu trūko drègmès, dirva buvo sausa, o balandžio antrą dekadą gausiai lijo. Ant dirvos paviršiaus susidarè pluta, cukriniai runkeliai dygo lètai. Skilčialapiai dirvos paviršiuje pasirodè tik gegužès 8 dieną. Birželio ir liepos

1 lentelè. Agrotechninès priemonès lauko bandymo vykdymo metais (ASU Bandymų stotis, 2011-2013 m.)

Table 1. Agrotechnical operations for the considered years of the field trial (Experimental Station ASU, 2011-2013)

Agrotechninès priemonès / Agrotechnical operations

1. Kompleksinių trąšų NPK 5:15:30 $400 \mathrm{~kg} \mathrm{ha}^{-1}$ išbèrimas / Fertilisation with complex fertiliser

2. Priešsejinis dirvos dirbimas / Presowing soil cultivation

3. Sèja / Planting

4. Herbicido Fiesta $51 \mathrm{ha}^{-1}$ išpurškimas / Application of Fiesta herbicide 5 l ha ${ }^{-1}$

5. Herbicido Betanal maxxPro 1,33 $1 \mathrm{ha}^{-1}$ išpurškimas / Application of Betanal maxxPro herbicide $1.33 \mathrm{l} \mathrm{ha}^{-1}$

6. Papildomas tręšimas amonio salietra $\left(\mathrm{N}_{34}\right) 180 \mathrm{~kg} \mathrm{ha}^{-1} /$ Additional fertilisation with ammonium saltpetre

7. 4 porų tikrųjų lapų augimo tarpsniu cukriniai runkeliai apipurkšti biologinių preparatų tirpalais / At the fourpairs-of-leaves stage of growth sugar-beet was sprayed with biological preparation solutions

8. Herbicido Betanal maxxPro 1,33 l ha ${ }^{-1}$ išpurškimas / Application of Betanal maxxPro herbicide 1.33 l ha ${ }^{-1}$

9. Išpurkštas insekticidas Proteus $0,751 \mathrm{ha}^{-1} /$ Application of insecticide Proteus $0.75 \mathrm{l} \mathrm{ha} \mathrm{h}^{-1}$

10. Papildomas patręšimas amonio salietra $\left(\mathrm{N}_{34}\right) 200 \mathrm{~kg} \mathrm{ha}^{-1} /$ Additional fertilisation with ammonium saltpetre

11. 6 porų tikrųjų lapų augimo tarpsniu cukriniai runkeliai antrą kartą pagal bandymų schemą apipurkšti biologiniu preparatu tirpalais / At the six-pairs-of-leaves stage of development sugar-beet was sprayed with biological preparation solutions for the second time

12. Laukas nupurkštas fungicido Maredo $0,8 \mathrm{l} \mathrm{ha}^{-1}$ tirpalu / Field treatment with fungicide Maredo $0.8 \mathrm{l} \mathrm{ha^{-1 }}$

13. Cukriniai runkeliai trečią kartą pagal bandymų schemą apipurkšti biologinių preparatų tirpalais / Sugar-beet was sprayed with biological preparation solutions for the third time 
mèn. vidutinè paros temperatūra ir kritulių kiekis buvo artimi daugiamečiams vidurkiams. Cukriniams runkeliams augti sąlygos buvo palankios. Augalams sustiprèti po nepalankių pavasarinių orų ir stimuliuoti cukrinių runkelių augimą labai padejo jų vegetacijos metu naudoti biologiniai preparatai. Rugpjūčio mèn. iškritęs gausesnis už daugiametị vidurkị kritulių kiekis cukriniams runkeliams žalingos įtakos neturèjo. Rugsejjis buvo vidutiniškai šiltas ir drègnas. Asimiliatų sintezei ir jų kaupimuisi šakniavaisiuose meteorologinès sąlygos buvo palankios.

2012 m. cukrinių runkelių sèjos metu dirva buvo drègna, tačiau po sejjos gausiai lijo. Cukrinių runkelių sèkloms dygti sąlygos nebuvo palankios. Gegužès pirmomis dekadomis labai trūko drègmès, dirvos paviršiuje susidarè kieta pluta. Cukriniai runkeliai dygo netolygiai, pasèlis atrodè retas. Pirma pora tikruju lapu susiformavo tik gegužès 20-21 dienomis. Birželio ir liepos mèn. vidutinè paros temperatūra buvo artima daugiametei, o kritulių iškrito šiek tiek daugiau už daugiameti vidurkį. Biologinių preparatų panaudojimas paskatino silpniau besivystančių cukrinių runkelių daigų intensyvesnị augimą. Rugpjūčio mèn. buvo šiltas, kritulių kiekis buvo artimas daugiamečiam vidurkiui. Cukriniams runkeliams augti ir vystytis sąlygos buvo palankios. Rugsèjo mèn. gausiai lijo. Dirva buvo užmirkusi, žemesnèse vietose telkèsi vanduo. Nuimti cukrinių runkelių derlių (spalio 4 d.) sąlygos nebuvo palankios.

2013 m. cukrinių runkelių sejjai sąlygos buvo tinkamos - dirva drègna, vidutinè paros temperatūra artima daugiametei. Tačiau antrą ir trečią balandžio dekadą kritulių iškrito labai mažai, dirva išdžiūvo. Gegužès pirmą dekadą kritulių visai nebuvo, todèl cukrinių runkelių sèkloms dygti ir daigams augti sąlygos buvo nepalankios. Augalai patyrè stresą, todèl labai pasiteisino 4 porų tikrujų lapų augimo tarpsniu cukrinių runkelių apipurškimas bandyme tirtųjų biologinių preparatų tirpalais. Pagerèjo augalų mitybos sąlygos bei atsparumas nepalankioms augimo sąlygoms. Gegužès antrą ir trečią dekadomis gausiai palijo. Birželio ir liepos mèn. buvo šilti, kritulių kiekis artimas daugiamečiam vidurkiui. Cukriniams runkeliams augti sąlygos buvo palankios. Rugsèjo mèn. - itin šiltas ir saulètas. Tai labai pagerino asimiliatų sintezę ir jų kaupimąsi šakniavaisiuose. Tačiau kritulių rugsèjo trečią dekadą iškrito gausiai, dirvos buvo imirkusios, tai apsunkino cukrinių runkeliu derliaus nuemimą.

2 lentelè. Meteorologinės sąlygos lauko bandymų vykdymo metais (Kauno meteorologijos stoties duomenys) Table 2. Meteorological conditions for the considered years of the field trial (Data of Kaunas Meteorological Station)

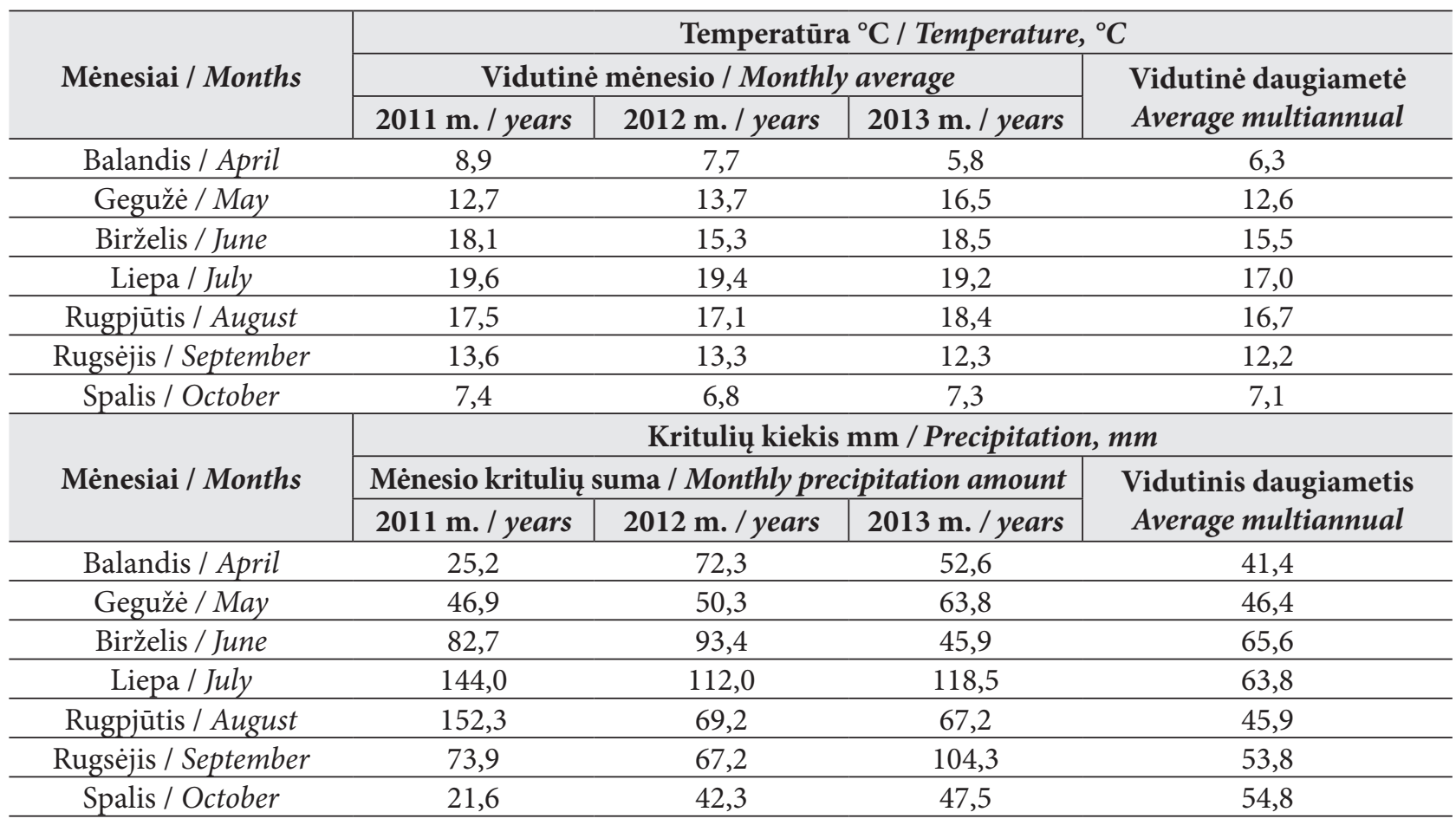




\section{TYRIMŲ REZULTATAI IR JŲ APTARIMAS}

Cukriniai runkeliai mineralines maisto medžiagas naudoja per visą vegetaciją, tačiau nevienodai skirtingais augimo tarpsniais. Jau pirmomis po sudygimo savaitèmis svarbu, kad augalai turètų pakankamai lengvai prieinamų maisto medžiagų. Tada jiems daugiausia reikia azoto ir fosforo. Tačiau ankstyvaisiais augimo tarpsniais (iki 4 poru tikrųjų lapų susiformavimo) cukriniai runkeliai labai jautrūs stresiniams veiksniams. Šiuo augimo laikotarpiu augalai patiria stresą net ir panaudo- jus herbicidus ar jų mišinius - sulètėja augimas, augalai praranda turgorą, sumažèja fotosintezès produktyvumas. Nuo stresų augalai gali prarasti iki $50 \%$ produktyvumo. Šiuo augimo periodu panaudoti biologiniai preparatai ne tik pagerina augalų mitybą, sumažina streso poveikį, bet ir užtikrina intensyvų augalų vegetatyvinès masès augimą (Jakiené, Spruogis ir kt., 2015).

Cukrinius runkelius 4 porų tikrųjų lapų augimo tarpsniu apipurškus bandyme tirtujų biologinių preparatų tirpalais, gautas patikimai didesnis šakniavaisių derlingumas (3 lentelè). Didžiausias teigiamas

3 lentelè. Biologinių preparatų naudojimo skirtingais cukrinių runkelių augimo ir vystymosi tarpsniais ịtaka šakniavaisių derlingumui (ASU Bandymų stotis, 2011-2013 m.)

Table 3. Influence of biological products use in different sugar beet growth and development stages on root yield (Experimental Station ASU, 2011-2013)

\begin{tabular}{|c|c|c|c|c|}
\hline \multirow{2}{*}{$\begin{array}{l}\text { Naudoti biologiniai preparatai } \\
\text { Applied biological preparations }\end{array}$} & \multicolumn{4}{|c|}{ Derlingumas t ha $^{-1} /$ Productivity tha $^{-1}$} \\
\hline & 2011 & 2012 & 2013 & 2011-2013 \\
\hline $\begin{array}{l}\text { Kontrole (biologiniai preparatai nenaudoti) } \\
\text { Control (Do not use biological preparations) }\end{array}$ & 60,20 & 68,18 & 65,14 & 64,50 \\
\hline \multicolumn{5}{|c|}{$16 \mathrm{BBCH}$ (4 porų tikrujjų lapų augimo tarpsnis) / BBCH (4 pairs of true leaf growth stage) } \\
\hline Azofit $11 \mathrm{ha}^{-1}$ & 67,62 & 77,03 & 73,25 & 72,63 \\
\hline Bioplant Fl. 11 ha $^{-1}$ & 65,54 & 74,49 & 72,23 & 70,75 \\
\hline Nagro $11 \mathrm{ha}^{-1}$ & 68,10 & 75,24 & 76,57 & 73,30 \\
\hline Raskila 21 ha $^{-1}$ & 63,00 & 74,34 & 70,38 & 69,24 \\
\hline $\mathrm{R}_{05} / L S D_{05}$ & 3,244 & 3,692 & 3,575 & 3,504 \\
\hline \multicolumn{5}{|c|}{$21 \mathrm{BBCH}$ (6 porų tikrujjų lapų augimo tarpsnis) / $21 \mathrm{BBCH}$ (6 pairs of true leaf growth stage) } \\
\hline Azofit $11 \mathrm{ha}^{-1}$ & 68,57 & 77,66 & 72,78 & 73,00 \\
\hline Bioplant Fl. $11 \mathrm{ha}^{-1}$ & 67,36 & 74,34 & 71,69 & 71,13 \\
\hline Nagro $11 \mathrm{ha}^{-1}$ & 69,54 & 76,75 & 74,78 & 73,69 \\
\hline Raskila 21 ha $^{-1}$ & 65,29 & 72,44 & 70,65 & 69,46 \\
\hline $\mathrm{R}_{05} / L S D_{05}$ & 3,309 & 3,683 & 3,550 & 3,517 \\
\hline \multicolumn{5}{|c|}{$33 \mathrm{BBCH}$ (lapai dengia $30 \%$ dirvos) / $33 \mathrm{BBCH}$ (leaves cover $30 \%$ soil) } \\
\hline Azofit $11 \mathrm{ha}^{-1}$ & 69,42 & 76,53 & 72,82 & 72,92 \\
\hline Bioplant Fl. 11 ha $^{-1}$ & 66,19 & 74,20 & 73,22 & 71,20 \\
\hline Nagro $11 \mathrm{ha}^{-1}$ & 68,76 & 75,96 & 75,63 & 73,45 \\
\hline Raskila 21 ha $^{-1}$ & 65,52 & 73,26 & 70,58 & 69,78 \\
\hline $\mathrm{R}_{05} / L S D_{05}$ & 3,301 & 3,681 & 3,573 & 3,518 \\
\hline \multicolumn{5}{|c|}{$16+21 \mathrm{BBCH} / 16+21 \mathrm{BBCH}$} \\
\hline Azofit $11 \mathrm{ha}^{-1}$ & 69,38 & 76,54 & 75,46 & 73,79 \\
\hline Bioplant Fl. 11 ha $^{-1}$ & 67,35 & 76,30 & 71,89 & 71,84 \\
\hline Nagro $11 \mathrm{ha}^{-1}$ & 70,64 & 77,10 & 74,45 & 74,06 \\
\hline Raskila 21 ha $^{-1}$ & 66,50 & 74,85 & 71,42 & 70,92 \\
\hline $\mathrm{R}_{05} / L S D_{05}$ & 3,340 & 3,729 & 3,583 & 3,551 \\
\hline \multicolumn{5}{|c|}{$16+21+33 \mathrm{BBCH} / 16+21+33 \mathrm{BBCH}$} \\
\hline Azofit $11 \mathrm{ha}^{-1}$ & 70,75 & 75,98 & 75,20 & 73,97 \\
\hline Bioplant Fl. 11 ha $^{-1}$ & 67,72 & 76,15 & 72,13 & 72,00 \\
\hline Nagro 11 ha $^{-1}$ & 70,45 & 78,20 & 75,33 & 74,66 \\
\hline Raskila 21 ha $^{-1}$ & 67,50 & 75,35 & 70,85 & 71,23 \\
\hline $\mathrm{R}_{05} / L S D_{05}$ & 3,366 & 3,738 & 3,586 & 3,563 \\
\hline
\end{tabular}


derlingumo pokytis gautas cukrinius runkelius apipurškus Azofit $11 \mathrm{ha}^{-1}$ ir Nagro $11 \mathrm{ha}^{-1}$ tirpalais. Šiuose bandymo laukeliuose prikasta atitinkamai 8,13 ir $8,80 \mathrm{t} \mathrm{ha}^{-1}$ šakniavaisių daugiau, palyginti su kontrole, kur biologiniai preparatai nebuvo naudoti. Cukrinius runkelius 4 porų tikrųjų lapu tarpsniu (16 BBCH) apipurškus Bioplant Flora $1 \mathrm{l} \mathrm{ha}^{-1}$ tirpalu, šakniavaisių derlingumas patikimai padidèjo $6,25 \mathrm{t} \mathrm{ha}^{-1}$, o šiuo augimo tarpsniu panaudojus biotrąšų Raskila 21 ha $^{-1}$ tirpalą gautas $4,74 \mathrm{t} \mathrm{ha}^{-1}$ patikimai didesnis šakniavaisių derlius, palyginti su kontroliniuose bandymo laukeliuose augusių cukrinių runkelių šakniavaisių derliumi.

Daugiausia mineralinių maisto elementų augalai sunaudoja intensyvaus augimo laikotarpiu, praejus maždaug šešioms savaitėms po sudygimo, kai augalai turi 6 poras ir daugiau tikrųjų lapų bei gali intensyviai asimiliuoti $\mathrm{CO}_{2}$ ir formuoti biologinę masę. Šis laikotarpis tęsiasi apie 3 mèn. (Feskova, Paauta, 2005).

Cukrinius runkelius tirtujų biologinių preparatų tirpalais apipurškus augalams suformavus 6 poras tikrųų lapų, didžiausias patikimas šakniavaisių derlius gautas taip pat apipurškus Azofit ir Nagro tirpalais. Panaudojus šiuos preparatus, gautas patikimai didesnis 8,50 ir 9,19 $\mathrm{t} \mathrm{ha}^{-1}$ derlingumo priedas, palyginti su kontrole. Cukrinius runkelius 6 porų tikrųjų lapų tarpsniu (21 $\mathrm{BBCH})$ apipurškus Bioplant Flora arba Raskila tirpalais, šakniavaisių derlingumas patikimai padidejo atitinkamai 6,63 ir 4,96 t ha ${ }^{-1}$, palyginti su kontroliniuose bandymo laukeliuose augusių cukrinių runkelių derlingumu.

Cukrinių runkelių apipurškimas biologiniais preparatais jų lapams dengiant $30 \%$ ir daugiau dirvos padeda augalams optimaliai paskirstyti mitybos elementų srautus iš lapų i Ł šaknis, sustiprina augalų imunitetą prieš tuo metu plintančias ligas. Šiuo augimo tarpsniu panaudojus biologinius preparatus Azofit ir Nagro, gautas 8,42 ir 8,95 t hapatikimai didesnis derliaus priedas, o cukrinius runkelius apipurškus Bioplant Flora arba Raskila tirpalais, šakniavaisių derlingumas padidejo $6,70 \mathrm{t} \mathrm{ha}^{-1}$ ir 5,28 $\mathrm{t} \mathrm{ha}^{-1}$, palyginti su kontrole, kur biologiniai preparatai nebuvo naudoti.

Cukrinius runkelius biologinių preparatų tirpalais apipurškus du kartus 4 ir 6 porų tikrųjų lapų augimo tarpsniu, yra optimizuojama augalų mityba, skatinamas biologinès masès augimas ne tik ankstyvaisiais augimo tarpsniais, bet ir cukrinių runkelių vystymosi laikotarpiu. Augalai greičiau suformuoja maksimalų asimiliacinį lapų plotą, kuris didele dalimi lemia fotosintetiškai aktyvios radiacijos (FAR) absorbavimą ir $\mathrm{CO}_{2}$ asimiliacijos intensyvumą fotosintezès procese.

Biologinius preparatus pagal cukrinių runkelių auginimo technologiją panaudojus du kartus, didžiausias esminis šakniavaisių derlingumo priedas $\left(9,29\right.$ ir 9,56 $\left.\mathrm{t} \mathrm{ha}^{-1}\right)$ gautas augalus apipurškus Azofit ir Nagro tirpalais. Dél biologinių preparatu Bioplant Flora ir Raskila itakos šakniavaisiu derlingumas, palyginti su kontrole, patikimai padidèjo 7,34 ir $6,42 \mathrm{tha}^{-1}$.

Didžiausi teigiami cukrinių runkelių derlingumo pokyčiai, palyginti su kontrole, gauti augalus bandyme tirtujų biologinių preparatų tirpalais apipurškus tris kartus (BBCG 16+21+33). Bandymo laukeliuose, kur cukriniai runkeliai tris kartus buvo apipurkšti Azofit ir Nagro tirpalais, šakniavaisių derlingumas siekè 73,97 ir 74,66 $\mathrm{t} \mathrm{ha}^{-1}$ arba buvo 9,47 ir $10,16 \mathrm{t} \mathrm{ha}^{-1}$ patikimai didesnis, nei kontroliniuose laukeliuose augusių cukrinių runkelių. Tačiau tarp derliaus priedų, gautų augalus šiais biologiniais preparatais apipurškus du ir tris kartus, esminių skirtumų nèra. Panašūs cukrinių runkelių derliaus priedai gauti ir augalus du ir tris kartus apipurškus biologinių preparatų Bioplant Flora (atitinkamai 7,34 ir 7,51 $\mathrm{t} \mathrm{ha}^{-1}$ ) ir Raskila $\left(6,42\right.$ ir $\left.6,73 \mathrm{t} \mathrm{ha}^{-1}\right)$ tirpalais. Todèl reiketu paskaičiuoti, ar ekonominiu požiūriu tikslinga cukrinius runkelius biologiniais preparatais purkšti tris kartus.

Cukriniai runkeliai - šviesamègiai augalai. Ilgomis, saulètomis dienomis didelis fotonų srauto tankis skatina augalo fotosintetinius procesus bei sacharozès sintezę. Šiuo augimo laikotarpiu biologinių preparatų naudojimas intensyvina lapų skaičiaus ir asimiliacinio ploto didejimą, formuojamas didesnis biologinis produktyvumas (Jakienè, Venskutonis, 2008).

Cukrinių runkelių daigus 4-6 porų tikrųjų lapu tarpsniu (16-21 BBCH) apipurškus bandyme tirtųjų biologinių preparatų tirpalais, intensyviau vyko fotosintezès ir medžiagų apykaitos procesai, šakniavaisiai sukaupe daugiau cukrinių medžiagu (1 pav.).

Cukringesni šakniavaisiai užaugo biologiniais preparatais vieną kartą apipurškus geriau išsivysčiusius augalus, kai jau buvo suformuotos 6 poros tikrųjų lapų. Šiuo augimo periodu panaudojus preparatus Azofit ir Nagro, nustatytas $0,81-1,03$ proc. 


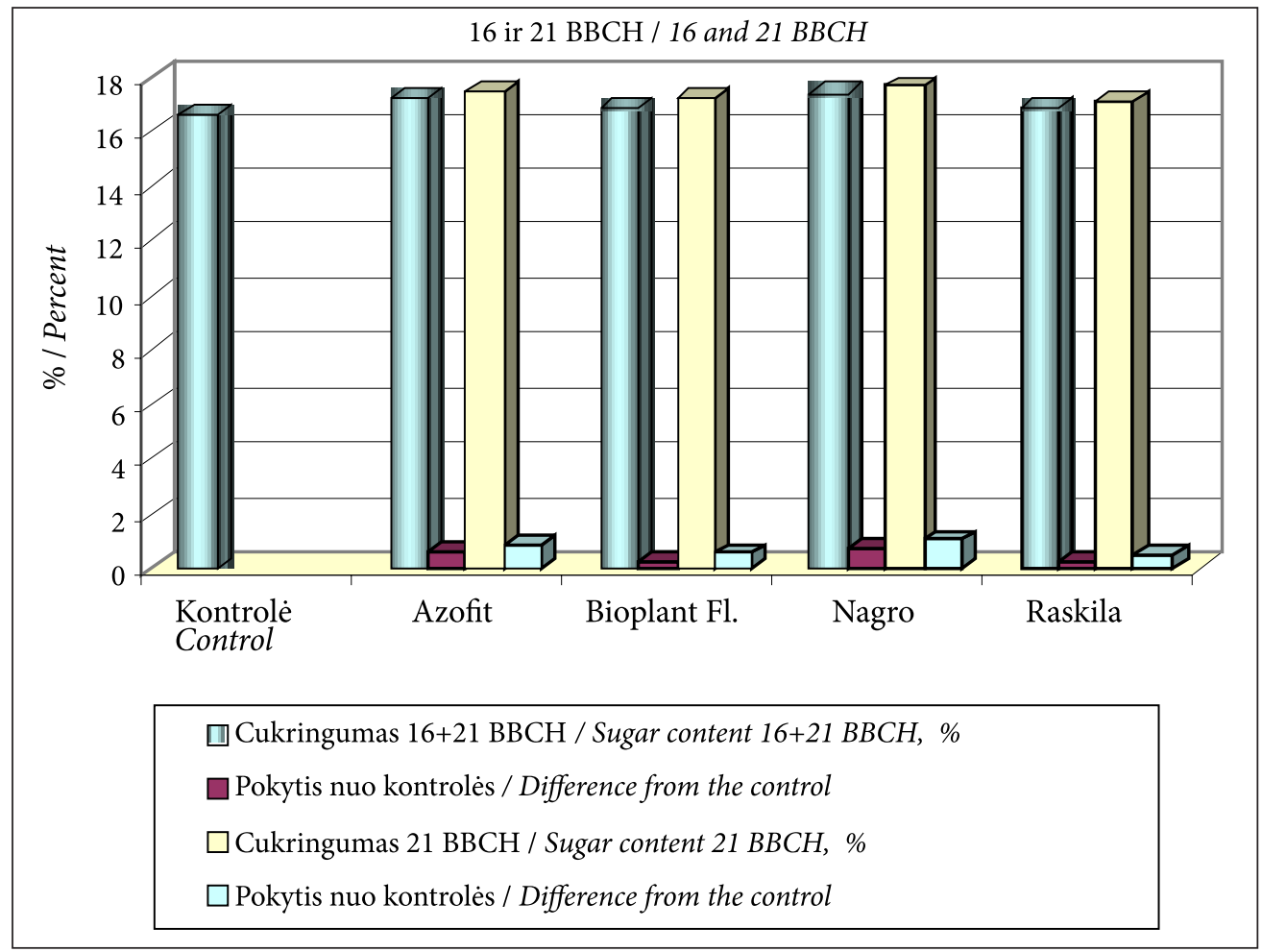

1 pav. Biologinių preparatų naudojimo 16 ir $21 \mathrm{BBCH}$ cukrinių runkelių augimo tarpsniais itaka šakniavaisių cukringumui (ASU Bandymų stotis, 2011-2013 m.)

Fig. 1. Influence of biological preparations use in 16 and $21 \mathrm{BBCH}$ growth stages of sugar beet on beetroots (Experimental Station ASU, 2011-2013)

vnt. patikimai didesnis šakniavaisių cukringumas, palyginti su kontrole. Dèl preparatų Bioplant Flora ir Raskila įtakos šakniavaisių cukringumas padidejjo vidutiniškai $\sim 0,5$ proc. vnt., tačiau šis padidèjimas nèra esminis.

Tirtaisiais biologiniais preparatais apipurškus cukrinių runkelių daigus jiems suformavus 4 poras tikrujų lapų, šakniavaisių cukringumas, palyginti su kontrole, padidejo nedaug ir nepatikimai.

Cukrinius runkelius vieną kartą apipurškus biologiniais preparatais, kai lapai denge $30 \%$ dirvos (33 BBCH), šakniavaisių cukringumas patikimai padidejo tik apipurškus Azofit ir Nagro tirpalais (2 pav.). Šiuose bandymo laukeliuose užaugusių šakniavaisių cukringumas nustatytas atitinkamai 0,80 ir 0,92 proc. vnt. didesnis, nei kontroliniuose bandymo laukeliuose augusių šakniavaisių. Cukrinius runkelius šiuo augimo tarpsniu apipurškus Bioplant Flora arba Raskila tirpalais, šakniavaisių cukringumas padidejo 0,64 ir 0,57 proc. vnt., palyginti su kontrole, tačiau šis padidejimas nèra esminis.
Daug geresni rezultatai gauti cukrinius runkelius tirtaisiais biologiniais preparatai apipurškus du ir tris kartus (3 pav.). Pagal cukrinių runkeliu auginimo technologiją biologinius preparatus panaudojus du kartus - augalams suformavus 4 ir 6 poras tikrųjų lapų, daugiausia cukrinių medžiagų sukaupe šakniavaisiai, kur augalai buvo apipurkšti preparatų Azofit ir Nagro tirpalais. Šiuose bandymo laukeliuose augusių šakniavaisių cukringumas nustatytas 0,99 ir 1,14 proc. vnt. patikimai didesnis, palyginti su kontrole.

Patikimai cukringumas padidejo ir augalus du kartus apipurškus preparatų Bioplant Flora ir Raskila tirpalais. Šiuose bandymo laukeliuose augusių šakniavaisių cukringumas nustatytas 0,83 ir 0,62 proc. vnt. didesnis, palyginti su kontrole.

Cukrinius runkelius tirtųjų biologinių preparatų tirpalais apipurškus tris kartus, cukringumo pokyčiai, palyginti su du kartus apipurkštų augalų šakniavaisių cukringumu, skyrèsi nedaug.

Biologinius preparatus cukrinių runkelių pasèlyje naudojant vieną kartą, tikslingiau būtų augalus 


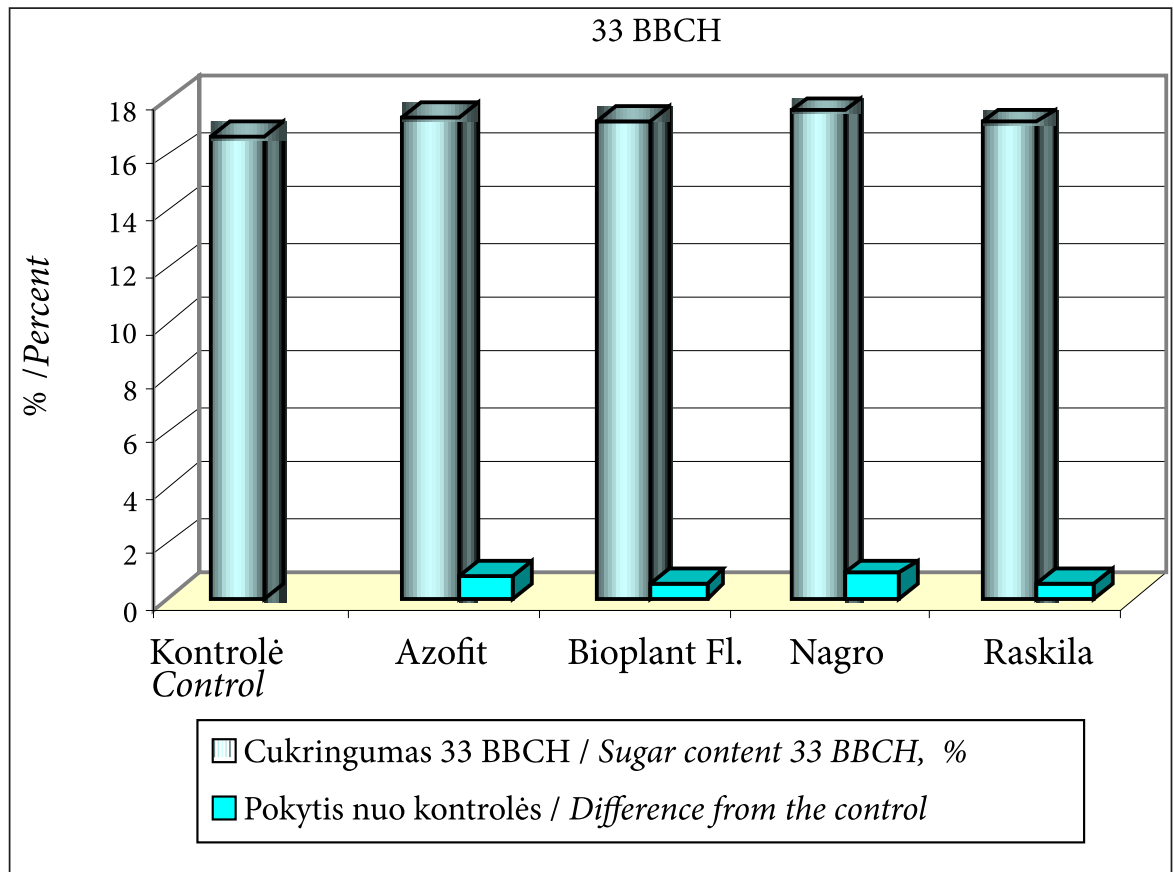

2 pav. Biologinių preparatų naudojimo $33 \mathrm{BBCH}$ cukrinių runkelių augimo tarpsniu įtaka šakniavaisių cukringumui (ASU Bandymų stotis, 2011-2013 m.)

Fig. 2. Influence of biological preparations use in $33 \mathrm{BBCH}$ growth stages of sugar beet on beetroots (Experimental Station ASU, 2011-2013)

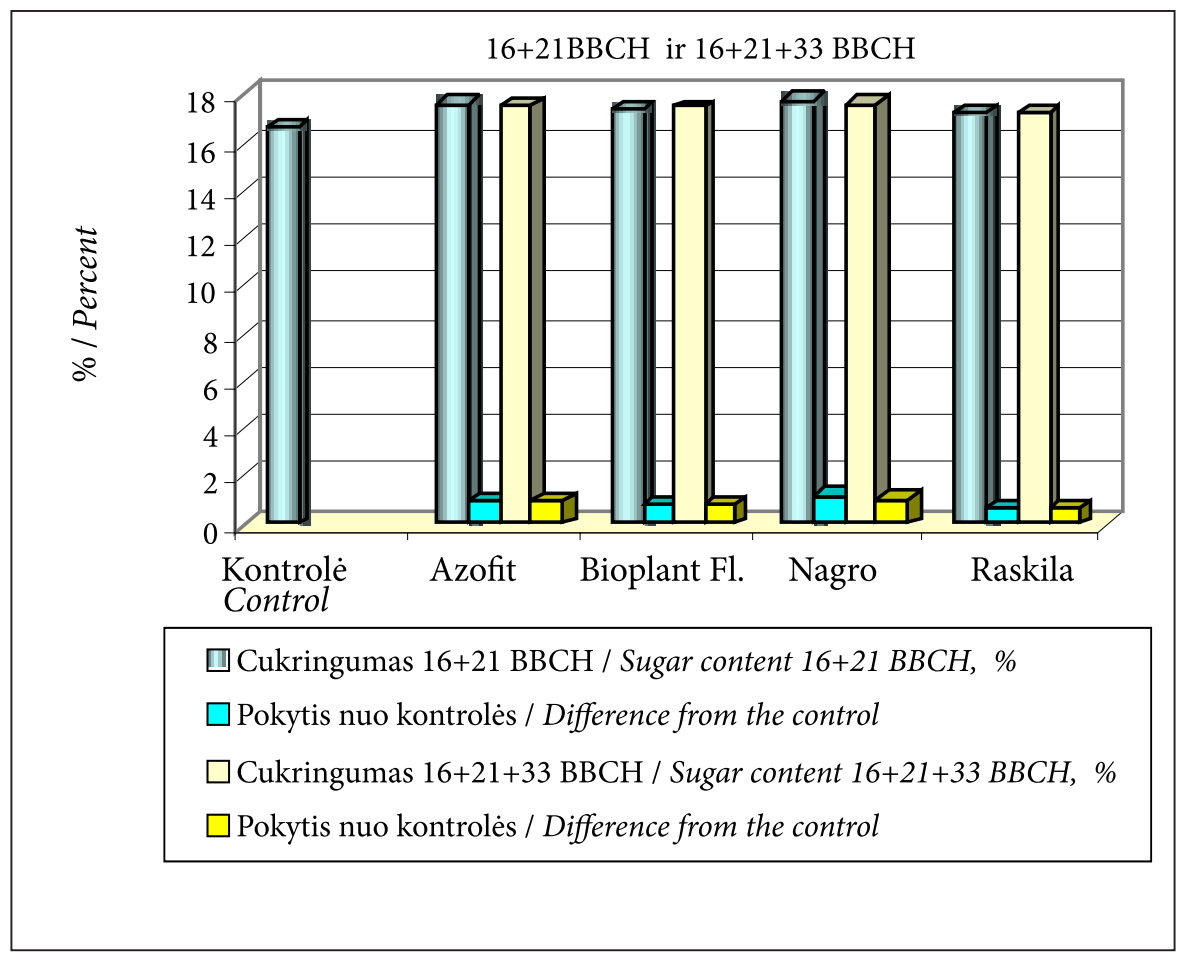

3 pav. Biologinių preparatų naudojimo $16+21 \mathrm{BBCH}$ ir $16+21+33 \mathrm{BBCH}$ cukrinių runkelių augimo periodu įtaka šakniavaisių cukringumui (ASU Bandymų stotis, 2011-2013 m.)

Fig. 3. Influence of biological preparations $16+21 \mathrm{BBCH}$ and $16+21+33 \mathrm{BBCH}$ growth stages of sugar beet on beetroots (Experimental Station ASU, 2011-2013) 
apipurkšti jiems esant $21 \mathrm{BBCH}$ ar vèliau, kol lapai neuždengè $\sim 30 \%$ dirvos. Šiuo metu vieną kartą panaudojus tirtuosius biologinius preparatus, gauta didžiausia baltojo cukraus išeiga. Mažiausia baltojo cukraus gauta cukrinius runkelius vieną kartą apipurškus 4 porų tikrụjų lapų augimo tarpsniu (2 lentelè).

Cukrinius runkelius biologinių preparatų tirpalais apipurškus vieną kartą, daugiausia baltojo cu- kraus gauta panaudojus Azofit ir Nagro tirpalus. Taip apipurškus augalus $21 \mathrm{BBCH}$ augimo tarpsniu, baltojo cukraus gauta 1,52 ir $1,90 \mathrm{t} \mathrm{ha}^{-1}$ arba 19,07 ir 23,83\% patikimai daugiau, palyginti su kontrole. Šų biologinių preparatų tirpalais cukrinius runkelius vieną kartą apipurškus $33 \mathrm{BBCH}$ augimo perio$\mathrm{du}$, baltojo cukraus gauta 1,63 ir $1,79 \mathrm{t} \mathrm{ha}^{-1}$ arba 20,45 ir 22,45\% patikimai daugiau, nei iš kontroliniuose bandymo laukeliuose augusių šakniavaisių.

4 lentelè. Biologinių preparatų naudojimo skirtingais cukrinių runkelių augimo ir vystymosi tarpsniais įtaka baltojo cukraus kiekiui (ASU Bandymų stotis, 2011-2013 m.)

Table 4. Influence of biological products use in different sugar beet growth and development stages on white sugar (Experimental Station ASU, 2011-2013)

Naudoti biologiniai preparatai Applied biological preparations

Kontrolè (biologiniai preparatai nenaudoti) Control (Do not use biological preparations)
Baltojo cukraus kiekis t ha $\mathrm{a}^{-1}$ / Amount of white sugar, $\mathrm{t} \mathrm{ha}^{-1}$

\begin{tabular}{l|l|l|l|}
2011 & 2012 & 2013 & $2011-2013$ \\
\hline
\end{tabular}

$\begin{array}{llll}7,95 & 7,82 & 8,15 & 7,97\end{array}$

\begin{tabular}{|c|c|c|c|c|}
\hline \multicolumn{5}{|c|}{$16 \mathrm{BBCH}$ (4 porų tikrųjų lapų augimo tarpsnis) / $16 \mathrm{BBCH}$ (4 pairs of true leaf growth stage) } \\
\hline Azofit $11 \mathrm{ha}^{-1}$ & 9,35 & 9,40 & 9,56 & 9,43 \\
\hline Bioplant Fl. $11 \mathrm{ha}^{-1}$ & 8,93 & 8,85 & 9,04 & 8,94 \\
\hline Nagro 11 ha $^{-1}$ & 9,58 & 9,45 & 9,83 & 9,62 \\
\hline Raskila 21 ha $^{-1}$ & 8,73 & 8,54 & 8,95 & 8,74 \\
\hline $\mathrm{R}_{05} / L S D_{05}$ & 0,445 & 0,440 & 0,465 & 0,447 \\
\hline \multicolumn{5}{|c|}{$21 \mathrm{BBCH}$ (6 porų tikrųjų lapų augimo tarpsnis) / 21 BBCH (6 pairs of true leaf growth stage) } \\
\hline Azofit 11 ha $^{-1}$ & 9,48 & 9,36 & 9,65 & 9,49 \\
\hline Bioplant Fl. $11 \mathrm{ha}^{-1}$ & 9,17 & 9,04 & 9,35 & 9,18 \\
\hline Nagro 11 ha $^{-1}$ & 9,85 & 9,67 & 10,10 & 9,87 \\
\hline Raskila 21 ha $^{-1}$ & 8,90 & 8,82 & 9,05 & 8,92 \\
\hline $\mathrm{R}_{05} / L S D_{05}$ & 0,453 & 0,448 & 0,463 & 0,454 \\
\hline \multicolumn{5}{|c|}{$33 \mathrm{BBCH}$ (lapai dengia $30 \%$ dirvos) / $33 \mathrm{BBCH}$ (leaves cover $30 \%$ soil) } \\
\hline Azofit $11 \mathrm{ha}^{-1}$ & 9,58 & 9,47 & 9,76 & 9,60 \\
\hline Bioplant Fl. 11 ha $^{-1}$ & 9,24 & 9,17 & 9,38 & 9,26 \\
\hline Nagro $11 \mathrm{ha}^{-1}$ & 9,74 & 9,62 & 9,93 & 9,76 \\
\hline Raskila 21 ha $^{-1}$ & 9,00 & 8,89 & 9,21 & 9,03 \\
\hline $\mathrm{R}_{05} / L S D_{05}$ & 0,455 & 0,449 & 0,464 & 0,456 \\
\hline \multicolumn{5}{|c|}{$16+21 \mathrm{BBCH} / 16+21 \mathrm{BBCH}$} \\
\hline Azofit 11 ha $^{-1}$ & 9,83 & 9,71 & 10,02 & 9,85 \\
\hline Bioplant Fl. 11 ha $^{-1}$ & 9,46 & 9,34 & 9,64 & 9,48 \\
\hline Nagro $11 \mathrm{ha}^{-1}$ & 9,98 & 9,87 & 10,16 & 10,00 \\
\hline Raskila 21 ha $^{-1}$ & 9,19 & 9,06 & 9,39 & 9,21 \\
\hline $\mathrm{R}_{05} / L S D_{05}$ & 0,464 & 0,458 & 0,473 & 0,465 \\
\hline \multicolumn{5}{|c|}{$16+21+33 \mathrm{BBCH} / 16+21+33 \mathrm{BBCH}$} \\
\hline Azofit $11 \mathrm{ha}^{-1}$ & 9,83 & 9,72 & 10,0 & 9,85 \\
\hline Bioplant Fl. 11 ha $^{-1}$ & 9,50 & 9,32 & 9,75 & 9,52 \\
\hline Nagro $11 \mathrm{ha}^{-1}$ & 9,97 & 9,84 & 10,17 & 9,99 \\
\hline Raskila $21 \mathrm{ha}^{-1}$ & 9,27 & 9,10 & 9,51 & 9,29 \\
\hline $\mathrm{R}_{05} / L S D_{05}$ & 0,465 & 0,458 & 0,475 & 0,466 \\
\hline
\end{tabular}


Cukrinius runkelius vieną kartą apipurškus Bioplant Flora arba Raskila tirpalais $21 \mathrm{BBCH}$ augimo tarpsniu, baltojo cukraus gauta 1,21 ir $0,95 \mathrm{t} \mathrm{ha}^{-1}$, o apipurškus $33 \mathrm{BBCH}$ augimo metu, atitinkamai 1,29 ir $1,06 \mathrm{t} \mathrm{ha}^{-1}$ arba 16,18 ir 13,29\% patikimai daugiau, palyginti su kontrole.

Didžiausia baltojo cukraus išeiga gauta biologinius preparatus pagal cukrinių runkelių auginimo technologiją panaudojus du arba tris kartus. $\mathrm{Du}$ kartus $(16+21 \mathrm{BBCH})$ augalus apipurškus Azofit arba Nagro tirpalais, gautas atitinkamai 1,88 ir $2,03 \mathrm{t} \mathrm{ha}^{-1}$ arba 23,58 ir $25,47 \%$ patikimai didesnis baltojo cukraus kiekis, palyginti su kontrole (2 lentelè). Augalams apipurkšti du kartus panaudojus Bioplant Flora arba Raskila tirpalus, baltojo cukraus gauta 1,51 ir $1,24 \mathrm{t} \mathrm{ha}^{-1}$ arba 18,94 ir $15,55 \%$ patikimai daugiau, nei iš kontroliniuose bandymo laukeliuose augusių šakniavaisių.

Cukrinius runkelius tirtaisiais biologiniais preparatais apipurškus tris kartus $(16+21+33 \mathrm{BBCH})$, gautas baltojo cukraus kiekis tik šiek tiek skyrèsi nuo baltojo cukraus kiekio, gauto augalus apipurškus du kartus. Todèl, remiantis gautais tyrimo rezultatais, galima teigti, kad efektyviau cukrinių runkelių pasèlyje biologinius preparatus naudoti augalus apipurškiant du kartus.

\section{IŠVADOS}

1. Tirtieji biologiniai preparatai esmingai didino cukrinių runkelių produktyvumą. Paséli $16 \mathrm{BBCH}$ augimo tarpsniu apipurškus Azofit arba Nagro 11 ha $^{-1}$ tirpalais, derlingumas patikimai padidejo 8,13 ir $8,80 \mathrm{t} \mathrm{ha}^{-1}$, cukringumas 0,62 ir 0,75 proc. vnt., baltojo cukraus $-1,46$ ir 1,65 $\mathrm{t} \mathrm{ha}^{-1}$, palyginti su kontroliniuose bandymo laukeliuose augusiais cukriniais runkeliais.

2. Šiais biologiniais preparatais runkelius apipurškus $21 \mathrm{BBCH}$ augimo periodu, šakniavaisių derlingumas esmingai padidèjo 8,50 ir $9,19 \mathrm{t} \mathrm{ha}^{-1}$, cukringumas - 0,81 ir 1,03 proc. vnt., baltojo cukraus kiekis $-1,52$ ir 1,90 $\mathrm{tha}^{-1}$, palyginti su kontrole. Panašūs patikimi derliaus priedai gauti ir cukrinius runkelius vieną kartą apipurškus $33 \mathrm{BBCH}$ augimo tarpsniu.

3. Geresni rezultatai gauti biologinius preparatus pagal cukrinių runkelių auginimo technologiją panaudojus keletą kartų. Augalus Azofit arba Nagro tirpalais apipurškus du kartus $(16+21 \mathrm{BBCH})$, šakniavaisių derlingumas esmin- gai padidejo 9,29 ir 9,56 t ha-1, cukringumas 0,99 ir 1,14 proc. vnt., baltojo cukraus gauta 1,88 ir 2,03 $\mathrm{t} \mathrm{ha}^{-1}$ patikimai daugiau, palyginti su kontrole.

4. Du kartus cukrinius runkelius apipurškus biologinių preparatų Bioplant Flora arba Raskila tirpalais, šakniavaisių derlingumas patikimai padidejo 7,34 ir 6,42 $\mathrm{t} \mathrm{ha}^{-1}$, cukringumas - 0,83 ir 0,62 proc. vnt., baltojo cukraus kiekis - 1,51 ir $1,24 \mathrm{t} \mathrm{ha}^{-1}$, palyginti su kontrole.

5. Cukrinius runkelius Azofit arba Nagro tirpalais apipurškus tris kartus $(16+21+33 \mathrm{BBCH})$, šakniavaisių derlingumas esmingai padidejo 9,47 ir $10,16 \mathrm{t} \mathrm{ha}^{-1}$, cukringumas $-0,95$ ir 1,02 proc. vnt., baltojo cukraus gauta 1,88 ir 2,02 $\mathrm{t} \mathrm{ha}^{-1}$ patikimai daugiau, nei kontroliniuose bandymo laukeliuose augusiu cukrinių runkelių, tačiau produktyvumo pokyčiai nebuvo didesni iš esmès, palyginti su gautais rezultatais, augalus biologiniu preparatų tirpalais apipurškus du kartus. Todèl galima teigti, kad biologiniu preparatų tirpalais tikslinga cukrinius runkelius apipurkšti du kartus 16 ir $21 \mathrm{BBCH}$ augimo tarpsniais.

Gauta 20150525

Priimta 20150914

\section{LITERATŪRA}

1. Bio-energy.LT/Bioplant flora [žiūrèta 2015-03-18]. Prieiga per internetą: http://www.bio-energy.lv/ LT/62/Bioplant Flora.htm

2. Darginavičienè J., Novickienè L. 2002. Augimo problemos šiuolaikinèje augalu fiziologijoje. Vilnius. $100 \mathrm{p}$.

3. Deveikytė I. 2000. Biological effectiveness of the mixture of herbicides for sugar beet. In: Development of Environmentally Friendly Plant Protection in the Baltic Region: Proceedings of the International Conference. Tartu. P. 28-30.

4. Deveikytė I., Petkevičienè B., Kaunas J. 2009. Cukriniai runkeliai. Agrobiologija, tyrimai, technologijos. Akademija, Kèdainių r. 255 p.

5. Dewar A. M., May M. J., Waiwod I. P. 2006. A novel approach to the use of genetically modified herbicide tolerant crops for environmental benefit. Biological Sciences: Proceedings of the Royal Society. Vol. 270. P. 35-340.

6. Drulis P. 2014. Inovatyvūs produktai - biologinès trąšos. Mano ūkis. Prieiga per internetą: manoukis. $\mathrm{lt} / . . / / 18395$-inovatyvus-produktai-biologines-trasos

7. Feckova J., Paauta V., Černy I. 2005. Effect of foliar preparations and variety on sugar beet yield and 
quality. Journal of Central European Agriculture. Vol. 6. No. 3. P. 295-308

8. Jakienè E., Spruogis V., Romaneckas K., Dautartè A., Avižienytė D. 2015. The bio-organic nano fertilizer improves sugar beet photosynthesis process and productivity. Žemdirbysté-Agriculture. Vol. 102. No. 2. P. 141-146.

9. Jakienė E., Venskutonis V. 2008. Augimo reguliatoriai augalininkystëje. Akademija. $80 \mathrm{p}$.

10. Jakienė E., Šlapakauskas V., Brazaitytè A., Sakalauskienè S., Mickevičius V., Duchovskis P. 2009. Skystųjų kompleksinių trąšų ir augimo reguliatorių itaka cukrinių runkelių fotosintezès rodikliams. Vagos: mokslo darbai. Nr. 85(38). P. 14-22.

11. Jakienè E., Šlapakauskas V., Mickevičius V., Sapijanskaitė B. 2008. Stilitų įtaka cukrinių runkelių šviesos absorbcijai, chlorofilų kaupimuisi ir produktyvumui. Žemés ūkio mokslai. T. 15. Nr. 2. P. $32-40$.

12. Kustodija.lt/azofit [žiūrèta 2015-03-10]. Prieiga per internetą: http://www.kustodija.lt/lt/produktas/2/Azofit

13. Lawlor D. W. 2005. Photosynthesis, productivity and environment. Journal of Experimental Botany. Vol. 46. P. 1449-1461.

14. Meier U. 2001. Growth Stages of Mono- and Dicotyledonous Plants. Phenological Growth Stages and $\mathrm{BBCH}$-Identification Keys of Beet. $\mathrm{BBCH}$ Monograph. P. 40-42.

15. Mickevičius V., Voskienè A., Jonuškienè I., Kolosej R., Šiugždaitė J., Venskutonis P. R., Kazernavičiūtė R., Brazienè Z., Jakienè E. 2013. Synthesis and biological activity of 3-[phenyl(1,3thiazol-2-yl)-amino]propanoic acids and their derivatives. Molecules. Vol. 18. No. 12. P. 1500015018.

16. NAGRO universalios trą̌sos [žiūrèta 2015-03-10]. Prieiga per internetą: http://nanonagro.lt/nagrouniversalios-trasos/

17. Narkevičius G., Šiuliauskas A., Liakas V., Romaneckas K. 2004. Šiuolaikinés augalininkystés technologijos. Akademija. 159 p.

18. Novickienè L. 1994. Augaly augima, vystymasi ir produktyvuma reguliuojančiu fitohormonu ir re- tardantu analogu kūrimo fiziologiniai pagrindai. Vilnius. P. 74-83.

19. Pekarskas J. 2008. Biologinių preparatų biojodžio ir „Biokal 1“ itaka ekologiškai auginamų burokèliu derliui ir biocheminei sudečiai. Sodininkystè ir daržininkysté: mokslo darbai. T. 27(4). P. 145-154.

20. Pidgeon J. D., Ober E. S., Qi A. 2006. Using multi-environment sugar beet variety trials to screen for drought tolerance. Field Crops Research. Vol. 95. Issues 2-3. P. 268-279.

21. Raskila [žiūrèta 2015-03-10]. Prieiga per internetą: http://www.rasakila.lt/

22. Romaneckas K., Kazėnas V., Žulienė R. 2001. Cukrinių runkelių pasèlių apšvitos ir lapų asimiliacinio paviršiaus ploto tyrimai. Vagos: mokslo darbai. T. 50(3). P. 41-45.

23. Romaneckas K., Romaneckienè R. 2009. Lapų trąšu poveikis cukrinių runkelių derliui ir kokybei. Vagos: mokslo darbai. Nr. 82(35). P. 41-47.

24. Shpaar D. 2006. Sakharnaya svyokla. DLV Agrodelo. $315 \mathrm{p}$.

25. Suojala T. 2000. Growth of and partitioning between shoot and storage root of carrot in northern climate. Agricultural and Food Science in Finland. Vol. 9. No. 1. P. 49-59.

26. Staugaitis G., Laure R. 2008. Lapų trąšų ịtaka cukriniu runkeliu derliui, kokybei ir pelningumui. Vagos: mokslo darbai. Nr. 78(31). P. 43-47.

27. Šiuliauskas A., Liakas V. 2012. Inovatyvios cukriniu runkeliu auginimo technologijos (žiūrèta 2015-0310). Prieiga per internetą: http: // www. Kustodija. lt / index. Php/lt/info/55

28. Šiuliauskas A., Liakas V. 2008. Azoto trašǔ normu itakos cukriniu runkeliu derliaus formavimuisi tyrimai mažo humusingumo dirvožemyje. Vagos: mokslo darbai. Nr. 78(31). P. 37-42.

29. Šlapakauskas V., Duchovskis P. 2008. Augaly produktyvumas. Kaunas. 253 p.

30. Tarakanovas P., Raudonius S. 2003. Agronominiu tyrimu duomenu statistine analize taikant kompiuterines programas ANOVA, STAT, SPLIT-PLOT iš paketo SELEKCIJA ir IRRISTAT. Akademija, $56 \mathrm{p}$. 
Elena Jakienė, Vidmantas Spruogis

\section{BIOLOGICAL PRODUCTS AND BIO-ORGANIC FERTILIZER USE IN SUGAR BEET}

\section{Sum mary}

The trials were carried out at the Experimental Station of Aleksandras Stulginskis University in 2011-2013. The effect of additional leaf spray fertilization with the solutions of biologic preparations Azofit 11 ha $^{-1}$, Nagro 11 ha $^{-1}$, Bioplant Flora $11 \mathrm{ha}^{-1}$ and Raskila $21 \mathrm{ha}^{-1}$ on the Ernestina variety of sugar beet roots (Beta vulgaris L., var. Saccharifera) was analysed. Before the sowing time the trial field was fertilized with NPK 5:15:30 $400 \mathrm{~kg} \mathrm{ha}^{-1}$ and additionally with amonium salphetre $\left(\mathrm{N}_{34}\right) 180 \mathrm{~kg} \mathrm{ha}^{-1}$ (background fertilization - control). Sugar beetroots were once leaf spray fertilized with the biologic preparations at $16 \mathrm{BBCH}, 21 \mathrm{BBCH}$ and $33 \mathrm{BBCH}$, twice at $16+21 \mathrm{BBCH}$, and three times at $16+21+33 \mathrm{BBCH}$ growth stages. Other agrotechnical measures were applied according to the sugar beetroot growing technology used at the Experimental Station. Sugar beetroots were harvested on 10 October. Root quality analysis was carried out at the LTD "Arvi Cukrus" Marijampolè Laboratory using the cold digestion method.

The obtained results revealed that the highest root yield and the best quality were obtained when sugar beetroots were once leaf spray fertilized with the solutions of biologic preparations Azofit $11 \mathrm{ha}^{-1}$ or Nagro $11 \mathrm{ha}^{-1}$ at the $21 \mathrm{BBCH}$ growth stage. This leaf spray fertilization resulted in the statistically significant sugar beetroot yield increase by
8.50 and $9.19 \mathrm{t} \mathrm{ha}^{-1}$, respectively, the root sugar content by 0.81 and 1.03 per cent per unit, respectively, the obtained amount of white sugar was by 1.52 and $1.90 \mathrm{tha}^{-1}$ reliably/ statistically higher than that obtained from the control.

When sugar beetroots were twice leaf spray fertilized with the solutions of biologic preparations Azofit $1 \mathrm{lha}^{-1}$ or Nagro $1 \mathrm{l} \mathrm{ha}^{-1}$ at the $16+21 \mathrm{BBCH}$ growth stage, the statistically significant sugar beetroot yield increase was by 9.29 and $9.56 \mathrm{t} \mathrm{ha}^{-1}$, respectively, the root sugar content by 0.99 and 1.14 per cent per unit, respectively, the obtained amount of white sugar was by 1.88 and $2.03 \mathrm{tha}^{-1}$ reliably/ statistically higher than that obtained from the control. When plants were twice leaf spray fertilized with the solutions of Bioplant Flora $1 \mathrm{l} \mathrm{ha}^{-1}$ or Raskila $2 \mathrm{l} \mathrm{ha}^{-1}$ biologic preparations, the statistically significant sugar beetroot yield increase was by 7.34 and $6.42 \mathrm{t} \mathrm{ha}^{-1}$, respectively, the root sugar content by 0.83 and 0.62 per cent per unit, respectively, the obtained amount of white sugar was by 1.51 and $1.24 \mathrm{t} \mathrm{ha}^{-1}$ reliably/statistically higher than that obtained from the control where biologic preparations were not applied.

The comparison of the results obtained after sugar beetroots were fertilized two times and three times at the stage $(16+21+33 \mathrm{BBCH})$ revealed no substantial changes in productivity.

The aim was to determine the optimal time of biologic preparations use for sugar beetroots.

Key words: sugar beetroots, biologic preparations, productivity, saccharinity 